\title{
The Urgency of Digital Literacy for Generation $Z$ Students in Chemistry Learning
}

\author{
https://doi.org/10.3991/ijet.v16i11.19871 \\ Citra Ayu Dewi $\left.{ }^{(}\right)$, Pahriah, Ary Purmadi \\ Universitas Pendidikan Mandalika, Mataram, Indonesia \\ ayudewi citra@ikipmataram.ac.id
}

\begin{abstract}
Chemistry learning is faced with problems that emphasize students' difficulty in learning the basic chemistry concepts to become increasingly difficult and less meaningful. Digital literacy can understand chemistry concepts and develop critical thinking skills because digital literacy emphasizes reading, writing, understanding, evaluating, communicating, and using the information in different formats. This research aims to determine digital literacy's role and urgency for generation $\mathrm{Z}$ students in chemistry learning. This research is descriptive qualitative research. The research subjects were chemistry education students of FSTT of Universitas Pendidikan Mandalika. In this study, there were two types of data; primary and secondary data. The primary data was collected through direct observation and interviews. Secondary data was collected through the literature review. The results showed that digital literacy is needed in chemistry learning by focusing on Generation $\mathrm{Z}$ students' needs in accessing the Internet as a medium to promises ease of community connectivity, starting from how to communicate, collaborate, be creative, solve problems, make decisions, and consume information. In chemistry learning, digital technology can help improve chemistry teaching quality in technical, cognitive, and social aspects. Also, digital technology has become necessary in chemistry learning because it can help students learn better with various ICT-enabled features that can motivate understanding of chemistry concepts and reduce cognitive memory load when studying ICT-based chemistry. Thus, digital literacy is urgent for Generation $\mathrm{Z}$ students in chemistry learning.
\end{abstract}

Keywords - Digital Literacy, Generation Z, Chemistry Learning

\section{Introduction}

In the technological revolution of the fourth industrial revolution, the world is now in heavy use of technological products. Knowledge flows from various sources without being deterred and filtered. This is the Age of Digital Disruption where the patterns of communication and IT, preferences, legislation, society, and the audience's atmosphere have responded [1]. In the modern age, massive change in life areas also impacts the learning process and how to relate to one another, how to learn [2][3], and learning environments from face-to-face classes to interactive online learning classes. The popularity of online learning continues to rise in tertiary education. Many higher 
education institutes are trying to provide students with new, flexible education opportunities while creating immersive digital learning experiences in attractive and efficient virtual classes (postgraduate) [4].

It is a significant challenge to provide Generation $\mathrm{Z}$ students with immersive learning opportunities, and the efforts to improve higher education pedagogy standards are the key motivations to reevaluate targeted approaches for higher education [5]. The strong desire to use technology to make learning resources easier, more extensive, and more varied to solve students' and educators' distance and enhance interaction and cooperation in online classrooms [6] is why education is required in virtual classrooms. Generation $\mathrm{Z}$ never experiences living without the Internet and has been brought up with unparalleled access to data and information [6]. They are highly capable of multi-tasking using a range of internet-enabled devices, including smartphones, tablets, laptops, and TVs [7][8]. This means their attention span is minimal, and this can be seen in the lecture halls as students get distracted and go online. Students nowadays want to participate actively in the learning process. Although they are highly digitally educated, they still value personal interaction and enjoy collaborative work. Advances in technology-enhanced learning, combined with new learning space designs, provide educators with new tools for flexible delivery and constructive knowledge in the classroom.

Thus, education should prepare human resources that cannot be replaced by the computer, think critically, imaginative, inventive, solve problems, interact better, and cooperate with people that would make them excel in workplaces. Human resources can possess this ability if the individual has skills such as digital literacy. However, it will not be obtained if the learning process only emphasizes old literacy competencies. For this reason, the education field needs to step up and strengthen new integrated literacy to enhance the competence and skills of scientific areas and careers.

Chemistry is a science which studies natural phenomena and laws based on matter and structure, features and changes in energy linked to some material modifications [10]. Chemistry education is known as the principles of education and chemistry itself, and thus chemistry learning aims to understand chemistry concepts. However, it is difficult for students to associate real-life circumstances with abstract chemistry concepts [11]. According to [12], chemistry education research is mostly about making students understand chemistry concepts better and creating meaningful chemistry learning. Thus, it is typically focused on learning strategies and media to help students understand concepts and other learning factors, including instruction and evaluation.

In this paper, chemistry learning faces a problem. Fundamental concepts need to be developed in education and training, while 21 st-century skills, mostly digital literacy, must be developed. Three chemical representations are concerned, including macro, micros, and symbolic [13]. These three representations need to be addressed by chemistry teachers so that chemistry concepts can be well understood. Regardless of these traits, students usually learn how to pass tests by memorizing facts and avoiding concepts. Therefore, learning chemistry is becoming harder and less meaningful. Students seldom receive news, in particular internet use. Moreover, it is essential to learn all aspects of digital literacy in chemistry because the student is still not capable of inter- 
preting and using technology. That is why access to knowledge is an essential indicator for students.

Chemistry learning should inspire students to find usefulness and practicality in chemistry to solve real-life problems from a chemistry perspective. Through digital literacy, students can grasp and think critically about chemistry concepts. Digital literacy is the capacity of a person to read and understand knowledge in the digital world. A study conducted by [14] found that higher computer software and hardware skills have positively impacted students' high learning outcomes. [15] showed that it affects the students' learning experiences (including digital literacy) such as internet access (access condition) in online learning and students' skill and activity to respond to educators during the conversation. Both poor management and quality of the online learning class management are factors in students' poor online learning performance. The skill to use digital technologies (digital competence) is influenced by digital literacy [14]. In contrast with America and Europe, Asia has a relatively low percentage at $8 \%$ in scientific research on digital literacy [16]. In Indonesia, only a few researches have examined this digital literacy. Previous research studies in Indonesia were mostly on information literacy, social media literacy, and ICT literacy in a particular community group. Internet access and social media use are sub-variables of digital literacy [17]. Thus, digital literacy becomes an urgent matter and needs to be immediately mastered by each individual as a compliment and the primary skill for internet users. This is in line with [18] that digital literacy is a gradual skill of living in the digital era indispensable for every individual.

This research aims to determine the role and urgency of understanding digital literacy for Generation Z students in chemistry learning. Digital literacy skill is an essential competency for humans in the development of the 21 st century. The researcher considered that Generation $\mathrm{Z}$ could not use well-developed cognitive skills related to the inability to filter digital rules and content used as learning media. The problems in this research are 1) Why is digital literacy important for Generation Z students? 2). How is digital literacy in chemistry teaching and learning? 3). Why is digital literacy important for chemistry learning?

\section{$2 \quad$ Literature Review}

\subsection{Digital literacy}

Digital literacy can be used and understood by various sources [19]. The aspects of digital literacy are (a) assembling knowledge by creating information from various credible sources; (b) information capacity; (c) the ability to read and understand nonsequential and complex information; (d) awareness of the context of media and its connection with network media (Internet); (e) awareness of network access that can be used as a reference and help; (f) filtration of incoming information; ( $g$ ) feel secure and have access to communication and knowledge [20]. The mastery of digital literacy needs to be balanced with different skills, particularly by Generation Z students, to prevent adverse developments due to digital literacy. In digital literacy, the main tar- 
gets are (1) digital and non-digital understanding format; (2) the creation and communication of digital information; (3) report; (4) assembling knowledge; (5) information literacy; (6) Media literacy [21]. Those competencies are a prerequisite that everyone, particularly Generation $\mathrm{Z}$ students, should master to use digital literacy to effectively, efficiently, and optimally support the learning process in and outside class.

\subsection{Generation $\mathrm{Z}$}

Generation $\mathrm{Z}$ has no experience living without the Internet and has been brought up with unparalleled access to data and information [22]. They are highly capable of multi-tasking using a range of internet-enabled devices, including smartphones, tablets, laptops, and TVs [23][24]. This means their attention span is minimal, and this can be seen in the lecture halls as students get distracted and go online. Advances in technology-enhanced learning, combined with new learning space designs, provide educators with new tools for flexible delivery and constructive knowledge in the classroom.

\subsection{Chemistry learning}

Chemistry learning in higher education aims to enable students to understand the fundamental theories, principles, concepts, and interrelated laws to apply their knowledge in everyday life [12]. The emphasis on chemistry studies is theoretical and practical, which requires digital literacy to develop critical thinking skills to solve problems [13]. In chemistry education, ICT can provide solutions to many of the issues that afflict chemistry education, thus improving chemistry education quality in chemistry. Chemistry extended information and communication technology, emphasizing tools and methods used in chemistry teaching in Higher Education because of the need for ICT to enhance students' knowledge and learning experience. There are many concepts chemical can be used to describe the motivational aspects of teaching and learning science through computers and ICT in learning.

\section{$3 \quad$ Methodology}

This research was conducted at the Chemistry Education Study Program of FSTT of Universitas Pendidikan Mandalika. The research subjects were chemistry education students. This type of research is descriptive qualitative research. Two types of data were used in this research; primary and secondary data. The primary data collection was done through direct observation and interviews to make direct observations of the object under study using the Internet as a digital medium in chemistry learning. Secondary data collection was done through the literature review to obtain theoretical foundations and support data relating to attempts to explore the complexities of knowing about the urgency of digital literacy for Generation $\mathrm{Z}$ students in chemistry learning. For data collection, the authors used in-depth interviews to recheck or prove information or previously obtained data. Also, a profound observation was optimized 
through chemistry's learning process. The instrument used to determine the role and urgency of understanding digital literacy for Generation $\mathrm{Z}$ students in chemistry learning was a questionnaire. The instrument used in this study was from the adaptation of existing digital literacy instruments [25]. The researcher developed it from the existing instruments by arranging 20 items according to the indicators. The instrument was then validated in content and language by three experts (expert judgment). Expert validation declared that 20 questions were valid in terms of content and language, so it is suitable for research. The distribution of questionnaire items is presented in Table 1 .

Table 1. Aspect of Item

\begin{tabular}{|l|l|c|}
\hline $\begin{array}{c}\text { Component } \\
\text { ofDigital Literacy }\end{array}$ & \multicolumn{1}{|c|}{ The sub-category of Digital Literacy } & Item \\
\hline Information & $\begin{array}{l}\text { Digital media to find digital information; to determine its im- } \\
\text { portance and goal }\end{array}$ & $1,2,3,4$ \\
\hline Communication & Sharing online tools of resources; to work with digital resources & $5,6,7,8$ \\
\hline Content Creation & $\begin{array}{l}\text { Integrating and reworking prior information and content; intel- } \\
\text { lectual property rights and permits handling and applying }\end{array}$ & $9,10,11,12$ \\
\hline Safety & $\begin{array}{l}\text { Security of personal and data; safe and sustainable use of pro- } \\
\text { tection measures }\end{array}$ & $13,14,15,16$ \\
\hline Problem-solving & $\begin{array}{l}\text { To make educated, purposeful, or essential decisions about best } \\
\text { digital resources; digital answers to philosophical issues. }\end{array}$ & $17,18,19,20$ \\
\hline
\end{tabular}

\section{$4 \quad$ Result and Discussion}

\subsection{Digital literacy is important for generation $\mathrm{Z}$ students}

Based on the results of observations and interviews, the components of digital literacy were shown. Students are free to review different types of new knowledge on the subject by showing the book or website as learning tools in the information component. Still, the Internet is also used to access or look for information related to learning and help students complete their assignments or homework. In the communication component, students are required to cooperate and collect information using digital devices. This communication skill is appropriate for students' chemistry learning competencies, namely communicating, using machines, inquiries, and problem solving, based on written papers, presentations, and guided explanations. In the content creation component, students should incorporate and rebuild their expertise directly after the event. This activity is according to the indicators of content creation, reconstructing experience. Students are trying to identify multiple virus-detected sites or applications in the safety component when collecting data from the Internet. They try to secure their equipment. In the problem-solving component, students encounter problems when run or read simulations at the data collection stage. This activity can therefore train their problem-solving skill. 
The results indicate that the Internet and digital technology's availability promises ease of community connectivity, starting from communicating, collaborating, being creative, solving problems, making decisions, and consuming information [26]. This is confirmed by a survey conducted by [1], which showed that $91 \%$ of the population uses the Internet, where the average time they spend using the Internet every day through any device is 8 hours 36 minutes. As a generation born in the digital era, internet access is necessary for Generation Z [28]. Five years ago, internet cafe was the primary place for children $(81 \%)$ and teenagers $(56 \%)$ to access the Internet. This year, internet cafes are replaced by homes, where $49 \%$ of children and $62 \%$ of teenagers access the Internet from their families [29]. This figure increased from $7 \%$ in children and $9 \%$ in teenagers, $93 \%$ of children and $97 \%$ of teenagers stated that they access the Internet through mobile devices, such as smartphones or gadgets [30]. Generation $\mathrm{Z}$ activities on the Internet are in social media, surfing the Internet, playing games, and listening to music [31]. The data shows that Generation Z students in Indonesia rely heavily on the Internet. However, their addiction to devices can give students an advantage if they can use the Internet to do something more productive, such as learning some skills, expanding material that has been learned in school, and others. Thus, digital literacy is urgent and needs to be directly mastered by every Generation $\mathrm{Z}$ student as a complement and primary skill for internet users. Digital literacy is critical, so digital literacy skills need to be developed. According to [32][33], the development of digital literacy is gradual. There are three levels of digital literacy:

1. Digital competence includes skills, concepts, approach, and behavior.

2. Digital usage refers to the implementation of digital competencies in particular contexts.

3. Digital transformation requires creativity and innovation in the digital world.

These three levels can be described as below (Figure 1). The three principles of development are the principle of gradual growth and must be started early on from the family, school, and community.

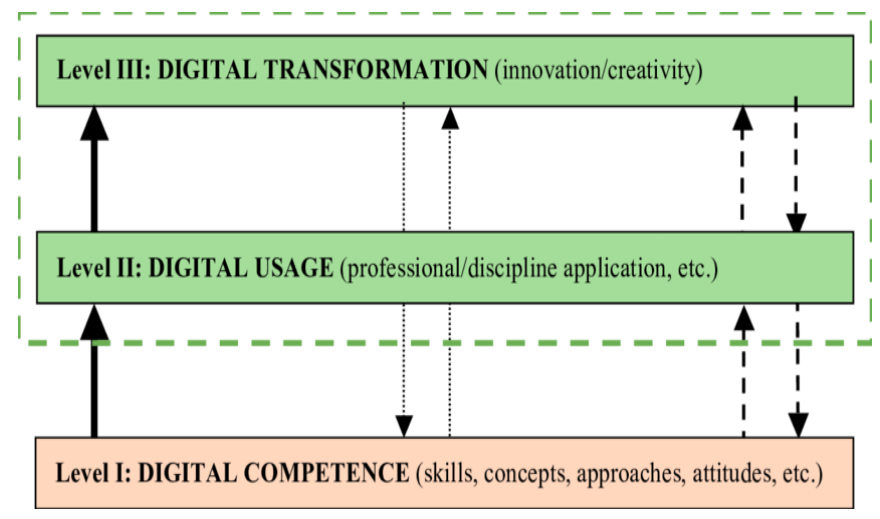

Fig. 1. Three Levels of Digital Literacy [32] 


\subsection{Digital literacy in chemistry teaching and learning}

In chemistry education, digital technology can provide solutions to various problems to improve chemistry education quality. Chemistry extends information and communication technology, focusing on using digital technology as chemistry learning tools and Generation Z students' methods. Several definitions can be used to explain the motivational aspects of chemistry learning. In chemistry learning, many subjects can be covered with the assistance of digital technology: aromaticity, 3D structure optimization, auto-renumbering, molar refractivity measurement, surface tension, paracord, refractive index, density, polarization and dielectric constant, IUPAC nomenclature, import and export molecules, 2D conversion in 3D. Thus, technological, digital literacy, cognitive and social dimensions used in chemistry education and learning are based on educational technology that promotes chemistry learning [34].

\section{The technical aspects of digital literacy}

Because of digital literacy, educators must be able to use ICTs in courses effectively. Teachers must a) realize students' potential, b) choose tools and methods according to student needs, c) design their teaching methods effectively, d) develop new teaching strategies, e) know and apply classroom management rules to solve problems encountered in environmental technology-assisted learning [35]. Digital literacy includes manuals for performing basic technical tasks or solving problems. Additionally, people who are digitally educated can look for online tools to solve problems. If people enter a correct keyword in the search engine, they will find text, photos, or videos to solve their problems. Understanding antivirus software and regular updates, the digital literature study includes spam and virus avoidance. The feature of digital literacy helps students read, perform, and complete certain activities using educational software. Popular types of educational software for studying chemistry are ChemSketch, Crocodile Chemistry, ChemDraw, JMol, Molegro Molecular, MarvinSketch, Hyperchem Sicyon.

In this case, technical aspects include downloading or installing programs from the Internet, removal, and extraction (if in ZIP type) on a computer [36]. Other technical skills are software control, knowing, and manipulating software, such as doubleclicking or highlighting, dragging, expanding, or dropping functions [37]. There are unique functions to be learned for any program, and the more realistic the software is, the better and more qualified it is [36]. With so much web content, digitally trained people can find knowledge to help them learn how to use apps [38].

\section{The cognitive aspects of digital literacy}

Digital students can analyze and select programs according to the analysis and each software application, select the best features/functions for problem-solving, or demonstrate an understanding of knowledge acquired. For instance, download Chemsketch graphics software to draw anything about chemistry. It can be removed manually or use the template provided. Students can draw gases, ions, stereo relations, documents, polygons, arrows, and laboratory devices, like an atom or molecule mass 
automatically. Digital literacy cognitive dimensions are also evident when online content is used. Much has been written about the information and resources needed to search, analyze, and use the web [39][40][41]. The competencies include analyzing content on web pages objectively in terms of precision, currency, reliability, and complexity [42]. In addition to criticism, a digitally literate individual is knowledgeable about legal, moral, and copyright issues regarding web material use [43].

\section{The social aspects of digital literacy}

Digital technology has become a lifestyle for young people through Internet access to e-mail, knowledge search, talk, post images, download games, videos and music, blogging, and wikis [44]. In chemistry learning, Web-based technology interactivity enables collaborative learning among online communities, for example, blogging about the subject of chemistry or contributing to scientific wikis. Awareness of safety and privacy and online etiquette is essential for them to engage socially and securely in online communities [45].

\subsection{Digital literacy is important for chemistry learning}

For a couple of reasons, digital literacy is essential for chemistry learning. It helps students learn better with the range of ICT-enabled features that can motivate understanding chemistry concepts. It also reduces cognitive memory load while learning ICT-based chemistry.

\section{Digital literacy and ICT-enabled features in chemistry education}

ICT chemistry pedagogy support includes numerous hardware and software, including interactive whiteboards, digital microscopes, simulations, interactive workbooks, electronic laboratory notebooks, scientific portals, multimedia edition tools, Web-based technologies, data recording, and software technologies. Teachers and students need sufficient digital literacy to use these tools for successful learning to achieve the desired learning outcomes. The Chemsketch, MarvinSketch, and Hyperchem applications that can be used to draw molecules are examples of the digital literacy level needed for ICT learning by chemicals students. There are topics covered by Chemsketch, MarvinSketch, and Hyperchem, including stereochemistry, Periodic Table, IUPAC Labeling, and 3D Structure.

\section{a) Stereochemistry}

An important branch of stereochemistry is chiral molecules. Stereochemistry is called 3D chemistry. Teaching stereochemistry with crack and speak is always a tedious activity for the teacher. It involves several 3D molecular structures, and it is not possible to draw 3D objects on the blackboard. Therefore, through the free Chemsketh and Hyperchem applications available on the Internet, 3D objects can quickly be drawn. Some other information, such as bond angles, angular strain, and chiral carbon, can be easily calculated. 

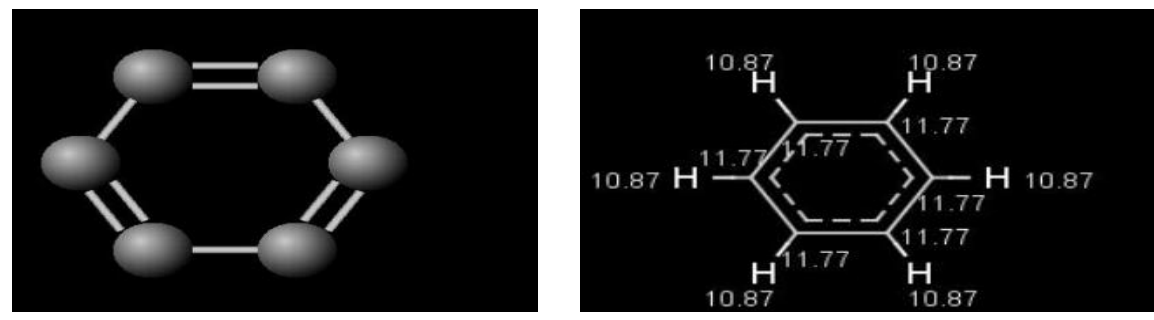

Fig. 2. Stereochemistry of benzene

\section{b) Periodic Table}

The periodic table is a concept for all facets of chemistry. Organic, inorganic, physical, medicinal, medical, and pharmaceutical chemistry. Nevertheless, understanding all the properties of the periodic table is still a challenge. This tool helps us learn more about regular tables. All atomic items 1 (Hydrogen) to 118 (Unununoctium) were found or synthesized, and IUPAC verified the elements $113,115,117$, and 118on December 30, 2015 (Chemistry: four elements added to the periodic table, BBC News). The standard table is organized as a complete grid. Because of its atomic structure, each component is placed in a specific location. As with any grid, the periodic table has rows and columns (up and down). Each row and column has characteristics. For example, in column two, Beryllium (Be and magnesium $(\mathrm{Mg}$ ) are found, sharing certain similarities while Potassium $(\mathrm{K})$ and Calcium $(\mathrm{Ca})$. The following is a picture of the periodic table using Marvinsketch.

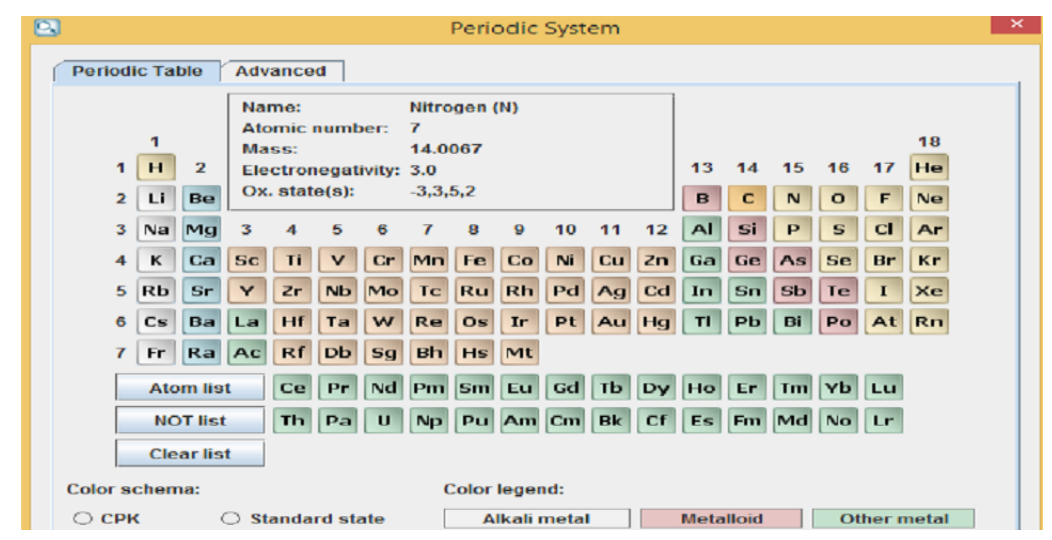

Fig. 3. Snapshot of Periodic Table

\section{c) IUPAC Naming}

In chemicals nomenclature, IUPAC organic chemistry nomenclature is a systemic approach for naming organic chemical compounds, as suggested by IUPAC. 


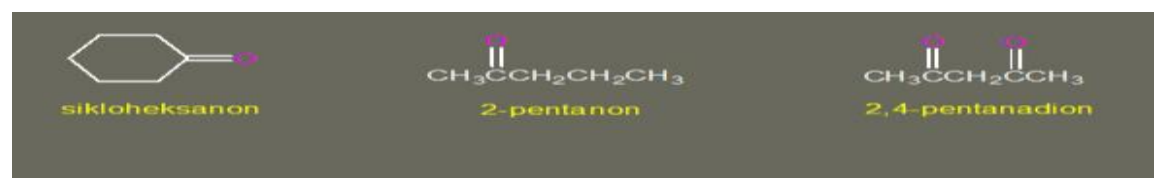

Fig. 4. IUPAC Nomenclature

\section{d) 3D Structure}

The 3D Structural Formula is an example of an amine molecule that molecular formulation is $\mathrm{CH} 3 \mathrm{CH} 2 \mathrm{NH} 2$. Amines are organic compounds containing trivalent nitrogen atoms, which are bonded to one or more carbon atoms. Compare the following representations of Amines:
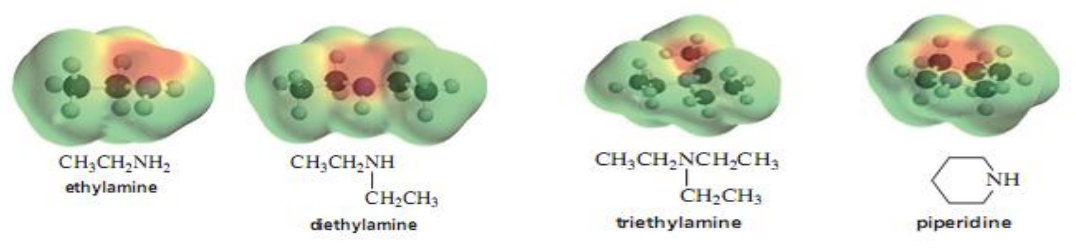

Fig. 5. 3 D Structure of Amines

The abstract nature of many concepts means that representation in chemistry studies is essential. Digital students can link different representations through multiple representations of the same concept [46][47][48].

\section{Digital literacy decreases the cognitive load of working memory when study- ing chemistry}

Research has shown that only a few elements can be processed through memorization learning [49]. When technological skills and experience in the involved technology are automatic, the student may concentrate his/her working history instead of technology on the task, minimizing cognitive strain. This follows the cognitive load theory [50], which says there are three mental load types:

1. Intrinsic cognitive charge. It is the inherent thing complexity associated with sophisticating the instructional content elements to be interpreted concurrently In the memory of working.

2. External loading. It depends on how the teacher introduces material for analysis and the burden of lousy teaching material design.

3. Loading Cognitive. Pressure from instructional materials promotes the learning process, e.g., motivational learning materials.

It means that teachers need to be competitive to integrate students into their teaching efficiently. It showed a firm technical experience and understanding of attractive technology strengths and constraints to design pedagogically useful technology to achieve students' desired learning outcomes. In classrooms, therefore, teachers must 
ensure that this technology does not draw students' attention and avoid the actual challenge of scientific research, setting the goal of using unique technology for chemistry learning. Students should be advised to use technology as a"free game" for a particular task and time, for example, by downloading Chemsketch's chemistry drawing graphics program. They can draw manually or use the template given. Click, draw and automate the mass, ions, stereo relations, manuals, arrows, and laboratory equipment of the atom or molecule. When exploring and familiarizing themselves with the latest technologies, the digitally trained teachers should note that apps are far better than those made a decade or two ago, so they do not crash so fast. Therefore, they should know that those steps can cause a device to crash completely by randomly clicking on tabs, menus, and hyperlinks. The further teachers study various applications, the more they understand that several parallels exist in the way they function. In gaining technical knowledge, teachers are not distracted from the pedagogic and educational fields, and students must recognize and enable them to meet students' technological challenges without too much effort. Thus, they can increase students' cognitive load by preparing engaging and relevant activities.

This research aims to provide solutions to various chemistry learning problems and help improve the quality of teaching in chemistry, especially the use of ICT as a tool that can enhance students' knowledge and learning experience. Many concepts can be used to describe the motivational aspects of chemistry learning through software applications that can be discussed, including aromaticity, optimization of 3D structures, tautomeric shapes, IUPAC nomenclature, conversion of $2 \mathrm{D}$ to $3 \mathrm{D}$, face shape of the periodic table, structure of carbohydrates, fullerenes and other large molecules, edit the molecular structure. Besides, ICT increases teacher efficiency and can reduce teacher time spent on administration tasks [25]. ICT plays a central role in the collaboration between schools and communities to involve parents in the learning process. Central authorities widely promote ICT as a tool for teaching and learning [26].

Some research showed that the lack of teachers' technical skills and the time required to develop them is a significant obstacle to the practical and enduring incorporation of ICT into schools [51][52][53]. Technological pedagogical content knowledge (TPACK) is a useful ICT integration model in education proposed by [54][55]. The model built on [55] Awareness of the Pedagogical Material (PCK) requires technical knowledge as part of technological teaching. Some research found this to be one of the critical factors that affect ICT success in education [56][57][58][59][60][61]. Teachers are prepared to develop digital literacy to interact with digital technology and integrate digital technology. For example, assistance from campus leaders (partnering with ICT experts) provides teachers' resources and technical support to solve problems quickly. It will go a long way toward increasing teachers' digital literacy.

\section{Conclusion}

It can be concluded that digital literacy is needed in chemistry learning by focusing on the needs of Generation $\mathrm{Z}$ students in accessing the Internet as a medium to access 
or find information related to education. In chemistry learning, digital technology can help improve chemistry teaching quality in technical, cognitive, and social aspects. Also, digital technology has become necessary in chemistry learning because it can help students learn better with various ICT-enabled features that can motivate understanding of chemistry concepts and reduce cognitive memory load when studying ICT-based chemistry. This research aims to provide solutions in chemistry learning and improve the quality of chemistry learning, especially using ICT as a medium that can increase students' knowledge and learning experience. This research's limitation focuses on the need for adequate digital literacy for Generation Z students in ICT as chemistry learning media. Next, the researcher suggests integrating technology into curriculum and instructional activities so that teachers understand how to use technology as an instructional tool in all disciplines.

\section{Acknowledgement}

The researcher would like to give the most generous gratitude to Ristekdikti's Director-General for funding this research project. Thank you to the Universitas Pendidikan Mandalika Mataram Principal for support, encouragement, and the Chairman of the LPPM UNDIKMA Mataram for research guidance.

\section{$7 \quad$ References}

[1] Liu, Z. J., Tretyakova, N., Fedorov, V., \& Kharakhordina, M. (2020). Digital literacy and digital didactics as the basis for new learning models development. International Journal of Emerging Technologies in Learning (iJET), 15(14), 4-18. https://doi.org/10.3991/ijet. v15i14.14669

[2] Bates, A.W. (2015). Teaching in a Digital Age, Ebook, Tony Bates Associates Ltd. ISBN 978-0-9952692-0-0.

[3] Nambisan, S., Lyytinen, K., Song, M. (2017). Digital innovation management: reinventing innovation management in a digital world. MIS Q. 41(1), 223-238. https://doi.org/10. 25300/misq/2017/41:1.03

[4] Mery, Y., \& Newby, J. (2014). Online by design. Lanham, MA: Rowman \& Littlefield Publishers.

[5] Hornsby, D. J., \& Osman, R. (2014). Massification in higher education: Large classes and student learning. Higher Education, 67(6), 711-719. https://doi.org/10.1007/s10734-0149733-1

[6] Siemens, G., Gaševic, D., \& Dawson, S. (2015). Preparing for the digital university: A review of the history and current state of distance, blended, and online learning. Arlington: Link Research Lab. Retrieved from: http://linkresearchlab.org/PreparingDigitalUniversity. pdf.

[7] Robertson, A. (2019). Preparing for Generation Z: how can technology-enhanced learning be firmly embedded in our students' learning experience? A case study from Abertay University. In 13th International Technology, Education and Development Conference (pp. 5769-5773). IATED Academy. https://doi.org/10.21125/inted.2019.1417

[8] Shatto, B., \& Erwin, K. (2016). Moving on from millennials: Preparing for generation Z. The Journal of Continuing Education in Nursing, 47(6), 253-254. https://doi.org/10.3928/ $\underline{00220124-20160518-05}$ 
[9] Carter, T. (2018). Preparing Generation $\mathrm{Z}$ for the teaching profession. STATE Journal, 27(1), 1-8.

[10] Neiles, K. Y., \& Bowers, R. A. (2020). A General Chemistry Curriculum Focused on the Development of Professional and Academic Skills. In Integrating Professional Skills into Undergraduate Chemistry Curricula (pp. 105-146). American Chemical Society. https:// doi.org/10.1021/bk-2020-1365.ch007

[11] Tekane, R., Pilcher, L. A., \& Potgieter, M. (2020). Blended learning in a second-year organic chemistry class: students' perceptions and preferences of the learning support. Chemistry Education Research and Practice, 21(1), 24-36. https://doi.org/10.1039 lc9rp00099b

[12] York, S., \& Orgill, M. (2020). ChEMIST Table: A Tool for Designing or Modifying Instruction for a Systems Thinking Approach in Chemistry Education. Journal of Chemical Education, 97(8), 2114-2129. https://doi.org/10.1021/acs.jchemed.0c00382

[13] Gkitzia, V., Salta, K., \& Tzougraki, C. (2020). Students' competence in translating between different types of chemical representations. Chemistry Education Research and Practice, 21(1), 307-330. https://doi.org/10.1039/c8rp00301g

[14] Spante, M., Hashemi, S. S., Lundin, M., \& Algers, A. (2018). Digital competence and digital literacy in higher education research: Systematic review of concept use. Cogent Education, 5(1), 1519143. https://doi.org/10.1080/2331186x.2018.1519143

[15] Anisimova, E. (2020). Digital Literacy of Future Preschool Teachers. Journal of Social Studies Education Research, 11(1), 230-253.

[16] Dorouka, P., Papadakis, S., \& Kalogiannakis, M. (2020). Tablets and apps for promoting robotics, mathematics, STEM education and literacy in early childhood education. International Journal of Mobile Learning and Organisation, 14(2), 255-274. https://doi.org/10. 1504/ijmlo.2020.10026334

[17] Jin, K. Y., Reichert, F., CagasanJr, L. P., de la Torre, J., \& Law, N. (2020). Measuring digital literacy across three age cohorts: Exploring test dimensionality and performance differences. Computers \& Education, 157, 103968. https://doi.org/10.1016/j.compedu.2020. $\underline{103968}$

[18] List, A., Brante, E. W., \& Klee, H. L. (2020). A framework of pre-service teachers' conceptions about digital literacy: Comparing the United States and Sweden. Computers \& Education, 148, 103788. https://doi.org/10.1016/j.compedu.2019.103788

[19] Papadakis, S., Vaiopoulou, J., Kalogiannakis, M., \& Stamovlasis, D. (2020). Developing and Exploring an Evaluation Tool for Educational Apps (ETEA) Targeting Kindergarten Children. Sustainability, 12(10), 4201. https://doi.org/10.3390/su12104201

[20] Kalogiannakis, M., Ampartzaki, M., Papadakis, S., \& Skaraki, E. (2018). Teaching natural science concepts to young children with mobile devices and hands-on activities. A case study. International Journal of Teaching and Case Studies, 9(2), 171-183. https://doi.org/ 10.1504/ijtcs.2018.10011893

[21] Gallardo-Williams, M., Morsch, L. A., Paye, C., \& Seery, M. K. (2020). Student-generated video in chemistry education. Chemistry Education Research and Practice, 21(2), 488-495. https://doi.org/10.1039/c9rp00182d

[22] Hernandez-de-Menendez, M., Díaz, C. A. E., \& Morales-Menendez, R. (2020). Educational experiences with Generation Z. International Journal on Interactive Design and Manufacturing (IJIDeM), 14(3), 847-859. https://doi.org/10.1007/s12008-020-00674-9

[23] Robertson, A. (2019, March). Preparing for Generation Z: how can technology-enhanced learning be firmly embedded in our students' learning experience? A case study from Abertay University. In 13th International Technology, Education and Development Conference (pp. 5769-5773). IATED Academy. https://doi.org/10.21125/inted.2019.1417

[24] Reddy, P., Sharma, B., \& Chaudhary, K. (2020). Digital literacy: A review of literature. International Journal of Technoethics (IJT), 11(2), 65-94. https://doi.org/10.4018/ijt.2020 $\underline{0701.0 a 1}$ 
[25] Agustini, D., Lian, B., \& Sari, A. P. (2020). School's Strategy for Teacher's Professionalism through Digital Literacy in the Industrial Revolution 4.0. International Journal of Educational Review, 2(2), 160-173. https://doi.org/10.33369/ijer.v2i2.10967

[26] Yildiz, E. P. (2020). Opinions of Academicians on Digital Literacy: A Phenomenology Study. Cypriot Journal of Educational Sciences, 15(3), 469-478. https://doi.org/10.18844/ cjes.v15i3.4913

[27] Helsper, E. J., \& Smahel, D. (2020). Excessive internet use by young Europeans: psychological vulnerability and digital literacy? Information, communication \& society, 23(9), 1255-1273. https://doi.org/10.1080/1369118x.2018.1563203

[28] Vollbrecht, H., Arora, V., Otero, S., Carey, K., Meltzer, D., \& Press, V. G. (2020). Evaluating the Need to Address Digital Literacy Among Hospitalized Patients: Cross-Sectional Observational Study. Journal of Medical Internet Research, 22(6), e17519. https://doi. org/10.2196/preprints. 17519

[29] Pereira, B. D., \& Pinheiro, P. C. (2020). The Development of a Formative Practice for Critical Digital Literacy and an Inquiry into its Effects within a Group of Pre-service Chemistry Teachers. Ciência \& Educação (Bauru), 26.

[30] Park, H., Kim, H. S., \& Park, H. W. (2020). A Scientometric Study of Digital Literacy, ICT Literacy, Information Literacy, and Media Literacy. Journal of Data and Information Science, 1 (ahead-of-print). https://doi.org/10.2478/jdis-2021-0001

[31] Polizzi, G. (2020). Digital literacy and the national curriculum for England: Learning from how the experts engage with and evaluate online content. Computers \& Education, 103859. https://doi.org/10.1016/j.compedu.2020.103859

[32] Nelson, K., Courier, M., \& Joseph, G. W. (2019). An investigation of digital literacy needs of students. Journal of Information Systems Education, 22(2), 2.

[33] Van Dyke, A. R. (2019). Practical Considerations for Advancing Undergraduate Digital Literacy through Digital Laboratory Notebooks.In Technology Integration in Chemistry Education and Research (TICER) (pp. 107-118). American Chemical Society. https://do i.org/10.1021/bk-2019-1318.ch007

[34] Silamut, A. A., \& Petsangsri, S. (2020). Self-directed learning with knowledge management model to enhance digital literacy abilities. Education and Information Technologies, 25(6), 4797-4815. https://doi.org/10.1007/s10639-020-10187-3

[35] Osman, K., \& Lay, A. N. (2019). Chemistry learning through designing digital games. In Advanced methodologies and technologies in media and communications (pp. 62-75). IGI Global. https://doi.org/10.4018/978-1-5225-7601-3.ch006

[36] Saputra, M., \& Al Siddiq, I. H. (2020). Social Media and Digital Citizenship: The Urgency of Digital Literacy in The Middle of A Disrupted Society Era. International Journal of Emerging Technologies in Learning (iJET), 15(07), 156-161. https://doi.org/10.3991/ijet. v15i07.13239

[37] Dori, Y. J., Rodrigues, S., \& Schanze, S. (2013). How to promote chemistry learning through the use of ICT. In Teaching chemistry-A studybook (pp. 213-240). Brill Sense. https://doi.org/10.1007/978-94-6209-140-5_8

[38] Gne, E., \& Bahivan, E. (2018). A mixed research-based model for pre-service science teachers' digital literacy. Computers \& Education, 118(C), 96-106.

[39] Morsch, L. A. (2016). Flipped teaching in organic chemistry using iPad devices. In The Flipped Classroom Volume 1: Background and Challenges (pp. 73-92). American Chemical Society. https://doi.org/10.1021/bk-2016-1223.ch006

[40] Mitchell, D. G., Morris, J. A., Meredith, J. M., \& Bishop, N. (2017). Chemistry infographics: Experimenting with creativity and information literacy. In Liberal arts strategies for the chemistry classroom (pp. 113-131). American Chemical Society. https://doi. org/10.1021/bk-2017-1266.ch007

[41] Zulkarnain, Z., Heleni, S., \& Thahir, M. (2020, October). Digital literacy skills of math students through e-learning in COVID-19 era: a case study in Universitas Riau. In Journal 
of Physics: Conference Series (Vol. 1663, No. 1, p. 012015). IOP Publishing. https://doi. org/10.1088/1742-6596/1663/1/012015

[42] Astuti, A. P., Mawarsari, V. D., Purnomo, H., \& Sediyono, E. (2020, April). The use of augmented reality-based learning media to develop the technology literacy of chemistry teachers in the 21st century. In AIP Conference Proceedings (Vol. 2215, No. 1, p. 020002). AIP Publishing LLC. https://doi.org/10.1063/5.0000745

[43] Hidayati, S. N., Fauziah, A. N. M., \& Subekti, H. (2019, August). The Effect of Socioscientific Issues Assisted of Virtual Learning to Improve Digital Literacy of Student.In 1st International Conference on Education Social Sciences and Humanities (ICESSHum 2019). Atlantis Press. https://doi.org/10.2991/icesshum-19.2019.37

[44] Buckingham, D. (2015). Defining digital literacy-What do young people need to know about digital media? Nordic journal of digital literacy, 10 (Jubileumsnummer), 21-35. https://doi.org/10.18261/issn1891-943x-2015-jubileumsnummer-03

[45] Townsend, J., Micucci, C. P., Hymel, J. H., Maroulas, V., \& Vogiatzis, K. D. (2020). Representation of molecular structures with persistent homology for machine learning applications in chemistry. Nature communications, 11(1), 1-9. https://doi.org/10.1038/s41467020-17423-x

[46] Upahi, J. E., \& Ramnarain, U. (2019). Representations of chemical phenomena in secondary school chemistry textbooks. Chemistry Education Research and Practice, 20(1), 146159. https://doi.org/10.1039/c8rp00191j

[47] Isaac, O., Aldholay, A., Abdullah, Z., \& Ramayah, T. (2019). Online learning usage within Yemeni higher education: The role of compatibility and task-technology fit as mediating variables in the IS success model. Computers \& Education, 136, 113-129. https://doi.org/ 10.1016/j.compedu.2019.02.012

[48] Bartsch, L. M., Loaiza, V. M., \& Oberauer, K. (2019). Does limited working memory capacity underlie age differences in associative long-term memory? Psychology and Aging, 34(2), 268. https://doi.org/10.1037/pag0000317

[49] Ginns, P., \& Leppink, J. (2019). Special Issue on Cognitive Load Theory. Educational Psychology Review, 1-5.

[50] Tondeur, J., Forkosh-Baruch, A., Prestridge, S., Albion, P., \& Edirisinghe, S. (2016). Responding to challenges in teacher professional development for ICT integration in education. Journal of educational technology \& society, 19(3), 110-120.

[51] Marwan, A., \& Sweeney, T. (2019). Using activity theory to analyse contradictions in English teachers' technology integration. The Asia-Pacific Education Researcher, 28(2), 115-125. https://doi.org/10.1007/s40299-018-0418-X

[52] Hong, H. Y., Lin, P. Y., \& Lee, Y. H. (2019). Developing effective knowledge-building environments through constructivist teaching beliefs and technology-integration knowledge: a survey of middle-school teachers in northern Taiwan. Learning and Individual Differences, 76, 101787. https://doi.org/10.1016/j.lindif.2019.101787

[53] Chai, C. S., Koh, J. H. L., \& Tsai, C. C. (2013). A review of technological pedagogical content knowledge. Journal of Educational Technology \& Society, 16(2), 31-51.

[54] Willis, R. L., Lynch, D., Fradale, P., \& Yeigh, T. (2019). Influences on purposeful implementation of ICT into the classroom: An exploratory study of K-12 teachers. Education and Information Technologies, 24(1), 63-77. https://doi.org/10.1007/s10639-018-9760-0

[55] Buabeng-Andoh, C. (2019). Factors That Influence Teachers' Pedagogical Use of ICT in Secondary Schools: A Case of Ghana. Contemporary Educational Technology, 10(3), 272288. https://doi.org/10.30935/cet.590099

[56] Habibi, A., Yusop, F. D., \& Razak, R. A. (2020). The role of TPACK in affecting preservice language teachers' ICT integration during teaching practices: Indonesian context. Education and Information Technologies, 25(3), 1929-1949. https://doi.org/10.1007/s106 $\underline{39-019-10040-2}$ 
[57] Haidari, M., Katawazai, R., \& Yusof, S. M. (2020). The Use of Social Media and Wikis in Teaching Writing Skills: A Review Article. International Journal of Interactive Mobile Technologies, 14(16). https://doi.org/10.3991/ijim.v14i16.15531

[58] Aisyah, E. N., Raharjo, K. M., \& Soraya, D. U. (2020). Transformation the Meaning of Learning for Millennial Generation on Digital Era. International Journal of Interactive Mobile Technologies, 14(12). https://doi.org/10.3991/ijim.v14i12.15579

[59] Papadakis, S. (2020). Tools for evaluating educational apps for young children: a systematic review of the literature. Interactive Technology and Smart Education. https://doi.org/ 10.1108/itse-08-2020-0127

[60] Drolia, M., Sifaki, E., Papadakis, S., \& Kalogiannakis, M. (2020). An Overview of Mobile Learning for Refugee Students: Juxtaposing Refugee Needs with Mobile Applications' Characteristics. Challenges, 11(2), 31. https://doi.org/10.3390/challe11020031

[61] Erna, M., Elfizar \& Dewi, C. A. (2021). The Development of E-Worksheet Using Kvisoft Flipbook Maker Software Based on Lesson Study to Improve Teacher's Critical Thinking Ability. International Journal of Interactive Mobile Technologies (iJIM), 15(1), 39-55. https://doi.org/10.3991/ijim.v15i01.15679

\section{Authors}

Citra Ayu Dewi is a senior lecturer in the Chemistry Education Department of Applied Science and Technique Faculty of Universitas Pendidikan Mandalika, Mataram, Indonesia, Jln. Pemuda 59A, Postcode 83125. Her research interest includes: developing model and media of learning, computer and internet-based learning, blended learning, and mobile learning. ORCID: 0000-0001-9381-9645. She is the Editor-in-Chief of the journal hydrogen (e-mail: ayudewi_citra@ikipmataram.ac.id)

Pariah is a senior lecturer in the Chemistry Education Department of Applied Science and Technique Faculty of Universitas Pendidikan Mandalika, Mataram, Indonesia, Jln. Pemuda 59A, Postcode 83125. Her research interest includes: developing models and media of learning (e-mail: pahriah@ikipmataram.ac.id)

Ary Purmadi is a lecturer in the Technology Education of Universitas Pendidikan Mandalika, Mataram, Indonesia, Jln. Pemuda 59A, Postcode 83125. Her research interest includes: developing a video of learning, computer and internet-based learning, and hybrid learning (e-mail: arypurmadi@ikipmataram.ac.id)

Article submitted 2020-11-16. Resubmitted 2021-01-26. Final acceptance 2021-01-26. Final version published as submitted by the authors. 